УДК 619:616.995

(C) 2016

Гугосьян Ю. А., аспірант

(науковий керівник - доктор ветеринарних наук, професор В. О. Євстаф'єва)

Полтавська державна аграрна академія

\title{
ЗМІНИ ГЕМАТОЛОГІЧНИХ ПОКАЗНИКІВ ЛОШАТ ЗА СТРОНГІЛОЇДОЗУ
}

\section{Рецензент - доктор ветеринарних наук, професор А. А. Замазій}

Вивчено вплив збудника стронгілоїдозу на морфологічні та біохімічні показники крові інвазованих лочат. Дослідженнями встановлено, щзо стронгілоїдозна інвазія супроводжується анемією, лейкоичтоозом $(13,46 \pm 1,03 \Gamma / л, p<0,001)$ та еозинофілією $(9,3 \pm 0,32 \%$, $p<0,001)$. У сироватиі крові хворих коней відмічено диспротеніемію на фоні гіпоальбумінемї $(p<0,001) i$ гіперглобулінеміі $(p<0,01)$, зростання активності аланін- та аспартатамінотрансфераз ( $<0,001)$, вмісту загального білірубіну $(15,12 \pm 2,38$ мкмоль/л, $p<0,01), \quad$ a також зниження вмісту глюкози $(3,12 \pm 0,92$ ммоль/л, $p<0,05)$.

Ключові слова: коні, стронгілоїдоз, кров, морфологічні, біохімічні показники.

Постановка проблеми. Процес життєдіяльності гельмінтів призводить до патологічних змін як безпосередньо у місцях їх локалізації або міграції, так і в цілому в організмі тварин $[1,5]$. Стронгілоїдеси, які паразитують у тонкому відділі кишечника, спричинюють запальні процеси і атрофію його ворсинок, що порушує процеси всмоктування, засвоєння і перетравлення поживних речовин. Личинки Strongyloides westeri, проникаючи в організм аліментарно або перкутанно, механічно пошкоджують цілісність тканин та органів, мігруючи кровоносною системою, виділяють токсини і метаболіти, спричинюючи інтоксикацію і сенсибілізацію організму коней $[1,8]$. У крові при цьому відмічають зміни морфологічних і біохімічних показників, рівень яких залежить від ступеня патогенної дії паразитів, інтенсивності інвазії, загальної резистентності та стану тварин [5].

Аналіз основних досліджень і публікацій, у яких започатковано розв'язання проблеми. В останні десятиріччя проблемі стронгілоїдозу тварин в Україні і вивченню його патогенного впливу на організм присвячено низку наукових робіт. Так, Х. М. Шендрик (2010) відмічала зміни гематологічних показників у телят, спонтанно уражених Strongyloides papillosus, які характеризувались еозинофілією, анемією, диспротеїнемією і гіпоглікемією [9].

Згідно 3 дослідженнями С. І. Пономаря (2013,
2014), стронгілоїдоз та змішана нематодозна інвазія у поросят супроводжується алергізацією, лейкоцитозом, короткочасним збільшенням кількості імунокомпетентних клітин та станом імуносупресії клітинної ланки імунітету [2, 7]. Однак питання патогенної дії Strongyloides westeri $\epsilon$ маловивченим у нашій країні і потребує додаткових досліджень.

Мета досліджень полягала у вивченні гематологічних показників у лошат уражених збудником стронгілоїдозу.

Завдання - дослідити рівень стронгілоїдозної інвазії у коней різного віку; визначити зміни морфологічних і біохімічних показників крові коней за спонтанного стронгілоїдозу.

Матеріали і методи досліджень. Дослідження проводили впродовж осіннього періоду 2016 р. в умовах «Спеціалізованої дитячо-юнацької спортивної школи Олімпійського резерву з кінного спорту» Дніпропетровської міської ради та приватних господарств коневласників Дніпропетровської області. Діагноз на стронгілоїдоз встановлювали за результатами копроовоскопічних досліджень за методом Котельникова-Хрєнова, інтенсивність інвазії визначали за методом В. Н. Трача.

3 метою визначення впливу на морфологічні та біохімічні показники коней за стронгілоїдозу було сформовано дві групи лошат до 18 місяців (по 5 тварин у кожній): дослідна (спонтанно уражені збудником стронгілоїдозу з середньою інтенсивністю інвазії - 264,1 559,3 яєць/г фекалій) та контрольна (клінічно здорові тварини).

Кров у тварин відбирали з яремної вени вранці перед годівлею. Підрахунок формених елементів крові здійснювали за допомогою автоматичного гематологічного аналізатора PCE - 90 Vet (США). В крові визначали: кількість еритроцитів, лейкоцитів, вміст гемоглобіну. Лейкоформулу виводили шляхом підрахунку лейкоцитів у мазках крові зафарбованих за РомановськимГімзою. Біохімічні показники встановлювали 3 використанням біохімічного аналізатора «Miura 200» (Італія). В сироватці крові визначали: вміст загального білка, альбумінової та глобулінової фракцій, білковий коефіцієнт, вміст сечовини, 
креатиніну, білірубіну (загального, прямого, непрямого), глюкози, активність аспартатамінотрансферази (АсАТ), аланінамінотрансферази (АлАТ).

Отримані результати обробляли статистично за допомогою комп'ютерної програми MS Excel 2003 шляхом визначення середнього арифметичного (M), його похибки (m) та рівня вірогідності (p) 3 використанням таблиці t-критеріїв Стьюдента [6].

Результати досліджень. За результатами власних досліджень встановлено, що екстенсивність стронгілоїдозної інвазії у коней дослідних господарств становила 30,9\%. Найвищі показники інвазованості реєстрували у лошат - 90 \% за II $264,1 \pm 59,3$ яєць/г. Клінічно стронгілоїдоз у хворих коней проявлявся зниженням апетиту, пері- одичною діареєю, приступами колік та відставанням у рості та розвитку. В організмі хворих тварин відмічали певні зміни морфологічних показників крові (табл. 1).

Як бачимо 3 даних таблиці 1, паразитування стронгілоїдесів в організмі лошат спричинювало зміни морфологічного складу крові. Так, у хворих тварин відмічали достовірне зменшення кількості еритроцитів на 25,79\% $\%(6,13 \pm 0,56$ T/л, $\mathrm{p}<0,001$ порівняно до показників у клінічно здорових лошат 8,26 $\pm 0,32$ T/л) та вмісту гемоглобіна на $34,69 \%(89,6 \pm 1,34$ г/л, $\mathbf{p}<0,001$ проти показників у контролі - 137,2 $\pm 0,78$ г/л), що свідчить про пригнічення еритропоезу та розвиток анемії в організмі уражених тварин.

\section{1. Гематологічні показники крові лочат хворих на стронгілоїдоз (n=5; $M \pm m$ )}

\begin{tabular}{|c|c|c|c|c|}
\hline \multicolumn{2}{|c|}{ Показники } & Контрольна група & Дослідна група & $\begin{array}{l}\text { Фізіологічні } \\
\text { коливання }^{\bullet}\end{array}$ \\
\hline \multicolumn{2}{|c|}{ Еритроцити, Т/л } & $8,26 \pm 0,32$ & $6,13 \pm 0,56 * * *$ & $6-9$ \\
\hline \multicolumn{2}{|c|}{ Лейкоцити, Г/л } & $9,67 \pm 0,42$ & $13,46 \pm 1,03 * * *$ & $6-11$ \\
\hline \multicolumn{2}{|c|}{ Гемоглобін, г/л } & $137,2 \pm 0,78$ & $89,6 \pm 1,34 * * *$ & $90-140$ \\
\hline \multicolumn{2}{|c|}{ Базофіли } & $1,2 \pm 0,26$ & $0,9 \pm 0,3$ & $0-1$ \\
\hline \multicolumn{2}{|c|}{ Еозинофіли } & $4,7 \pm 0,33$ & $9,3 \pm 0,32 * * *$ & $1-5$ \\
\hline \multicolumn{5}{|c|}{ Лейкоформула, \% } \\
\hline \multirow{3}{*}{ Нейтрофіли } & Ю & 0 & 0 & 0 \\
\hline & $\Pi$ & $3,8 \pm 0,48$ & $9,2 \pm 0,27 * * *$ & $2-6$ \\
\hline & $\mathrm{C}$ & $40,4 \pm 2,79$ & $34,8 \pm 2,45 * *$ & $45-65$ \\
\hline \multicolumn{2}{|c|}{ Лімфоцити } & $43,2 \pm 1,51$ & $34,6 \pm 1,42 * * *$ & $25-45$ \\
\hline \multicolumn{2}{|c|}{ Моноцити } & $1,7 \pm 0,8$ & $1,2 \pm 0,38$ & $0-4$ \\
\hline
\end{tabular}

Примітка: * - $<<0,05 ; * *-\mathrm{p}<0,01 ; * * *-\mathrm{p}<0,001-$ відносно показників контрольної групи;

- - фізіологічні коливання показників подані за В. В. Влізло і ін. (2008) [4].

\section{2. Біохімічні показники сироватки крові лошат за стронгілоїдозу (n=5; $M \pm m)$}

\begin{tabular}{|c|c|c|c|}
\hline Показники & Контрольна група & Дослідна група & $\begin{array}{c}\text { Фізіологічні } \\
\text { коливання }\end{array}$ \\
\hline Загальний білок, г/л & $78,63 \pm 3,47$ & $70,47 \pm 2,76^{* * *}$ & $65-80$ \\
\hline Альбуміни, г/л & $41,27 \pm 1,69$ & $30,59 \pm 2,03 * * *$ & $35-45$ \\
\hline Глобуліни, г/л & $37,36 \pm 1,35$ & $39,88 \pm 1,42^{* *}$ & $30-37$ \\
\hline Білковий коефіцієнт, од. & $1,10 \pm 0,36$ & $0,81 \pm 0,33$ & $1,2-1,8$ \\
\hline Сечовина, ммоль/л & $3,92 \pm 0,25$ & $4,16 \pm 0,37$ & $3,5-6,0$ \\
\hline Креатинін, мкмоль/л & $118,12 \pm 4,75$ & $123,45 \pm 5,41$ & $100-160$ \\
\hline АсАТ, Од/л & $189,33 \pm 4,84$ & $286,27 \pm 5,74^{* * *}$ & $115-290$ \\
\hline АлАТ, Од/л & $15,23 \pm 0,27$ & $28,26 \pm 0,35^{* * *}$ & $5-30$ \\
\hline Лужна фосфатаза, Од/л & $145,75 \pm 12,32$ & $157,23 \pm 13,43$ & $100-250$ \\
\hline Білірубін загальний, мкмоль/л & $10,56 \pm 1,76$ & $15,12 \pm 2,38^{* *}$ & $4,0-14,5$ \\
\hline Білірубін прямий, мкмоль/л & $2,76 \pm 0,84$ & $4,32 \pm 1,85$ & $0,5-3,5$ \\
\hline Білірубін непрямий, мкмоль/л & $7,79 \pm 1,46$ & $11,23 \pm 2,36 *$ & $3,5-11$ \\
\hline Глюкоза, ммоль/л & $4,11 \pm 0,54$ & $3,12 \pm 0,92^{*}$ & $3,0-5,0$ \\
\hline
\end{tabular}

Примітка: *-p<0,05; ** - $<<0,01 ; * * *-p<0,001$ - відносно показників контрольної групи;

- - фізіологічні коливання показників подані за В. В. Влізло й ін. (2008) [4] та В. І. Левченко, В. В. Влізло, І. П. Кондрахін і ін. [3]. 
Підвищення кількості лейкоцитів на 39,19\% $(13,46 \pm 1,03$ Г/л, $p<0,001$ проти показників у конт-

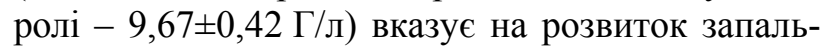
них процесів та гострий перебіг захворювання.

Одночасно в крові хворих лошат відмічали еозинофілію $(9,3 \pm 0,32 \%, \mathrm{p}<0,001$ проти показників у

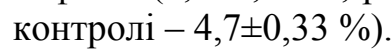

В лейкоформулі інвазованих лошат реєстрували підвищення кількості паличкоядерних нейтрофілів у 2,4 рази $(9,2 \pm 0,27 \%, \mathrm{p}<0,001)$, зменшення сегментоядерних нейтрофілів у 1,16 разів $(34,8 \pm 2,45 \%, \mathrm{p}<0,01)$ та кількості лімфоцитів на $19,9 \%(34,6 \pm 1,42 \%, \mathrm{p}<0,001)$, що вказує на імуносупресивну дію стронгілоїдесів і зниження опірності організму внаслідок їх патогенного впливу.

Зміни біохімічних показників сироватки крові за спонтанного стронгілоїдозу наведені у таблиці 2.

За результатами біохімічних досліджень встановлено достовірне зниження вмісту загального білку у сироватці крові інвазованих лошат на $10,38 \%(70,47 \pm 2,76$ г/л, $\mathrm{p}<0,001$ проти показни-

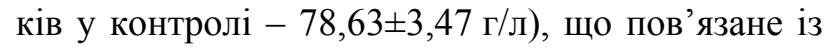
недоотриманням організмом протеїну, внаслідок порушення перетравлювання i засвоєння його епітеліальними клітинами кишечника.

Аналіз складу білків сироватки крові показав зниження вмісту альбумінів на $25,87 \%$ $(30,59 \pm 2,03$ г/л, $<<0,001)$ та підвищення вмісту глобулінів на $6,32 \%(39,88 \pm 1,42$ г/л, $\mathrm{p}<0,01)$ порівняно з показниками у тварин дослідної групи.

Зниження альбумінової фракції вказує на порушення процесів його синтезу в гепатоцитах, а наявність при цьому гіпопротеінемії та диспротеїнемії, внаслідок підвищення глобулінової фракції, свідчить про появу запальних процесів у

\section{БІБЛІОГРАФІЯ}

1. Вислобоков В. А. Стронгилоидоз лошадей в центральном районе Нечерноземной зоны Российской Федерации: биология возбудителя, эпизоотология, патогенез, лечение и профилактика : дис. ... к.вет.н. / В. А. Вислобоков. - Иваново, 2009. $-150 \mathrm{c}$.

2. Зміни гематологічних показників до та після лікування телят за стронгілоїдозу / [Пономар С. I., Шендрик Л. І., Шендрик Х. М. та ін.] // Науковотехнічний бюлетень НДЦ біобезпеки та екологічного контролю ресурсів АПК. - Дніпропетровськ, 2014. - Т. 2, №2. - С. 112-118.

3. Лабораторна діагностика у ветеринарній медицині / [Влізло В. В., Максимович І. А., Галяс В. Л., Леньо М. І.]. - Львів, 2008. - 112 с.

4. Клінічна діагностика внутрішніх хвороб тварин / [Левченко В. І., Влізло В. В., Кондрахін І. П. кишечнику.

Одночасно виявляли зростання активності АсАТ i АлАТ у 1,5 i 1,9 разів відповідно ( $<<0,001)$, що, на нашу думку, пов'язане з токсичною дією продуктів виділення стронгілоїдесів та руйнацією гепатоцитів.

Вміст загального білірубіну у сироватці крові тварин дослідної групи становив $15,12 \pm 2,38$ мкмоль/л, що на $30,16 \%$ більше $(\mathrm{p}<0,01)$, ніж аналогічний показник у контролі (10,56 $\pm 1,76$ мкмоль/л).

Таке його збільшення відбулося за рахунок підвищення вмісту непрямого білірубіну (на $30,63 \%, \mathrm{p}<0,05)$.

Достовірне зниження вмісту глюкози в сироватці крові контрольних тварин (на 24,09\%, $\mathrm{p}<0,05)$ можливо пояснити зниженням засвоєння 1ii у кишечнику та порушенням глюконеогенезу в печінці.

Таким чином, результати змін гематологічних показників лошат за спонтанного стронгілоїдозу свідчать про порушення гомеостазу та патогенний вплив збудника на їх організм.

\section{Висновки:}

1. Паразитування стронгілоїдесів в організмі лошат призводить до змін у морфологічному складі крові, що проявляється анемією, лейкоцитозом та еозинофілією.

2. Біохімічні показники сироватки крові інвазованих стронгілоїдесами лошат характеризуються розвитком гіпопротеїнемії, альбумінемії, гіперглобулінемії, гіпербілірубінемії, гіпоглікемії та зростанням активності АсАТ, АлАТ.

У подальшому планується вивчити гематологічні показники лошат, хворих на стронгілоїдоз, у процесі їх лікування.

та ін.]. - Біла Церква, 2004. - 608 с.

5. Манойло Ю. Б. Гематологічні показники хворих свиней за різної інтенсивності езофагостомозної інвазії / Ю.Б.Манойло // Науковотехнічний бюлетень НДЦ біобезпеки та екологічного контролю ресурсів АПК. - Дніпропетровськ, 2016. - Т. 4, №2. - С. 74-77.

6. Мельниченко О. П. Статистична обробка експериментальних даних : навчальний посібник / О. П. Мельниченко, І. Л. Якименко, Р. Л. Шевченко. - Біла Церква, 2006. - 34 с.

7. Пономар С. I. Стронгілоїдоз та змішана нематодозна інвазія свиней : автореф. дис. ... д.вет.н. : спец. 16.00.11 «Паразитологія» / С. І. Пономар. К. : НУБіПУ, 2013. - 40 с.

8. Ткаченко A. B. Влияние стронгилоидозной инвазии на морфологические, биохимические и 
иммунобиологические показатели крови и разработка методов их коррекции при терапии лошадей : автореф. дисс. ... к.б.н. : спец. 03.00.19 «Паразитология» / А. В. Ткаченко. - Тюмень, 2009. - 18 c.
9. Усенко-Шендрик $X . M$. Зміни показників крові у телят, уражених стронгілоїдозом / Х. М. Усенко-Шендрик // Науковий вісник Національного університету біоресурсів і природокористування України. - 2010. - Вип. 151. - Ч. 2. C. 199-202. 